10. Daly RC, Pairolero PC, Piehler JM, Trastek VF, Payne WS, Bernatz PE. Pulmonary aspergilloma: results of surgical treatment. J Thorac Cardiovasc Surg 1986;92:981-8.

11. Karas A, Hankins JR, Attar S, Miller JE, MLaughlin JS. Pulmonary aspergilloma: an analysis of 41 patients. Ann Thorac Surg 1976;22:1-7.

12. McPherson P. Pulmonary aspergillosis in Argyll [letter]. Br J Dis Chest 1965;59:148.

13. The Research Committee of the British Tuberculosis Association. Aspergillus in persistent lung cavities after tuberculosis. Tubercle 1968;49:1-4.

14. Temeck BK, Venzon DJ, Moskaluk CA, Pass HI. Thoracotomy for pulmonary mycoses in non-HIV immuno-suppressed patients. Ann Thorac Surg 1994;58:333-8.

15. Bernard A, Caillot D, Casasnovas O, Couaillier JF, Guy H, Favre JP. The value of surgery in the treatment of invasive pulmonary aspergillosis in neutropenic patients. Rev Mal Respir 1998;15:49-55.

16. Young VK, Maghur HA, Luke DA, McGovern EM. Operation for cavitating invasive pulmonary aspergillosis in immunocompromised patients. Ann Thorac Surg 1992;53:621-4.

17. Jewkes J, Kay PH, Paneth M, Citron KM. Pulmonary aspergilloma: analysis of prognosis in relation to haemoptysis and survey of treatment. Thorax 1983;38:572-8.
18. Chatzimichalis A, Massard G, Kessler R, Barsotti P, Claudon B, Ojard-Chillet $\mathrm{J}$, et al. Bronchopulmonary aspergilloma: a reappraisal. Ann Thorac Surg 1998;65:927-96.

19. Salerno CT, Ouyang DW, Pederson TS, Larson DM, Shake JP, Johnson EM, et al. Surgical therapy for pulmonary aspergillosis in immunocompromised patients. Ann Thorac Surg 1998;65:1415-9.

20. Saab SB, Almond C. Surgical aspects of pulmonary aspergillosis. J Thorac Cardiovasc Surg 1974;68:455-60.

21. Rafferty P, Biggs BA, Crompton GK, Grant IWB. What happens to patients with pulmonary aspergilloma? Analysis of 23 cases. Thorax 1983;38:579-83.

22. Shirakusa T, Ueda H, Saito T, Matsuba K, Kouno J, Hirota N. Surgical treatment of pulmonary aspergilloma and Aspergillus empyema. Ann Thorac Surg 1989;48:779-82.

23. Rosenberg RS, Creviston SA, Schonfeld AJ. Invasive aspergillosis complicating resection of a pulmonary aspergilloma in a non-immunosuppressed host. Am Rev Respir Dis 1982;126:1113-5.

24. Borelli D, Bran JL, Fuentes J, Legendre R, Leiderman E, Levine $\mathrm{HB}$, et al. Ketoconazole, an oral antifungal: laboratory and clinical assessment of imidazole drugs. Postgrad Med J 1979;55:657-61.

25. Gerstl B, Weidman WH, Newman AV. Pulmonary aspergillosis: report of two cases. Ann Intern Med 1948;28:662-4.

\title{
Availability of Journal back issues
}

As a service to our subscribers, copies of back issues of The Journal of Thoracic and Cardiovascular Surgery for the preceding 5 years are maintained and are available for purchase from Mosby until inventory is depleted. The following quantity discounts are available: $25 \%$ off on quantities of 12 to 23, and one third off on quantities of 24 or more. Please write to Mosby, Inc, Subscription Services, 11830 Westline Industrial Drive, St Louis, MO 63146-3318, or call 800-453-4351 or 314-453-4351 for information on availability of particular issues and prices. If unavailable from the publisher, photocopies of complete issues may be purchased from Bell \& Howell Information and Learning, $300 \mathrm{~N}$ Zeeb Rd, Ann Arbor, MI 48106-1346; 734-761-4700 or 800-521-0600. 